\title{
ACTINOMYCOSIS OF THE CANALICULI* WITH INVASION OF TISSUE IN ONE CASE
}

BY

\section{J. GIBSON MOORE}

London

ACTINOMYCosis infection of the lacrimal canaliculi is a well-recognized condition in ophthalmic practice. Invasion of the tissues of the host is well known in other parts of the body but there appears to be only one previously recorded case where the canaliculi have been invaded (Chesneau, 1908).

Examination may reveal a swelling in the region of the punctum which superficially may look like a meibomian cyst, but this condition does not occur here. If, on milking the canaliculus, a purulent discharge is noted, the diagnosis is almost certain (Theodore, 1950).

In all the cases here recorded the punctum was patulous; in the opening a dirty white mass could be seen but the concretions could never be expressed manually. These concretions require to be curetted out and are hard and friable but can be crushed between a slide and cover slip for microscopic examination. The term "sulphur-granule" is misleading, as the colour is more often a dirty-white with a greenish tinge rather than yellow. The diagnosis can thus be made on clinical grounds alone, but all these cases were confirmed microscopically.

Reports of the frequency of the condition vary. Kipp (1902) reports that of 101,100 eye conditions treated in 21 years only three had this affection, and that in the Brooklyn Eye and Ear Hospital only four cases were noted in 32 years out of a total of 181,729. Wissmann (1913), however, states that it forms 2 per cent. of all lacrimal diseases. In the past 2 years I have a record of six cases, and it would thus appear to be not too uncommon. It is even possible that the condition may be becoming more frequent because of the increase in the use of antibiotics, causing suppression of the normal bacterial flora which may produce a factor inhibitory to the growth of the fungus.

\section{TREATMENT}

It is pleasing to find such a condition where the line of action is clear and dramatic in its results. The punctum is dilated and split for $1 \mathrm{~mm}$., or just sufficient to admit a small chalazion spoon, and the concretions are curetted out. The quantity of material which can be obtained is often remarkable. The small slit in the canaliculus does not appear to disturb the drainage of tears. No further treatment has been required, and no case has recurred. I have tried other (conservative) measures such as the infiltration of the area with high concentrations

* Received for publication May 8, 1952. 
of penicillin and the instillation into the lacrimal sac of aqueous penicillin or a 1 per cent. tincture of iodine or potassium iodide but without success.

\section{Case Reports}

All six cases were female and, apart from one old lady of 86 , were between 30 and 45 years of age. It is dangerous to draw conclusions from such a tiny series, but this frequency in women agrees with the majority of previously recorded cases and as this is the characteristic age group and sex in which "idiopathic" epiphora occurs it would appear that that embarrassment of tear drainage is a necessary factor to encourage the growth of the anaerobic fungus. However, Brinckerhoff (1942) and McClanahan (1936) describe cases in males aged 19 and 14 years respectively.

In three cases the lower canaliculus was involved, in two the upper, and in the remaining one both were affected.

All the cases cleared up within a few days of the removal of the concretions, and the lacrimal passages were freely patent both before and after treatment.

Case 6, Housewife, aged 40, complained of a mucopurulent discharge from the right eye for the past year. She had been given penicillin drops during this time with no improvement. Examination revealed a normal white eye without any signs of follicular conjunctivitis. The lower punctum was gaping with a dirty white plug in its mouth. Near the caruncle, in the line of the canaliculus, there was a white mass the size of a grain of corn bathed in mucopus (Figure). The diagnosis of actinomycosis was confirmed microscopically in the pus and later in the actual concretion (see below).

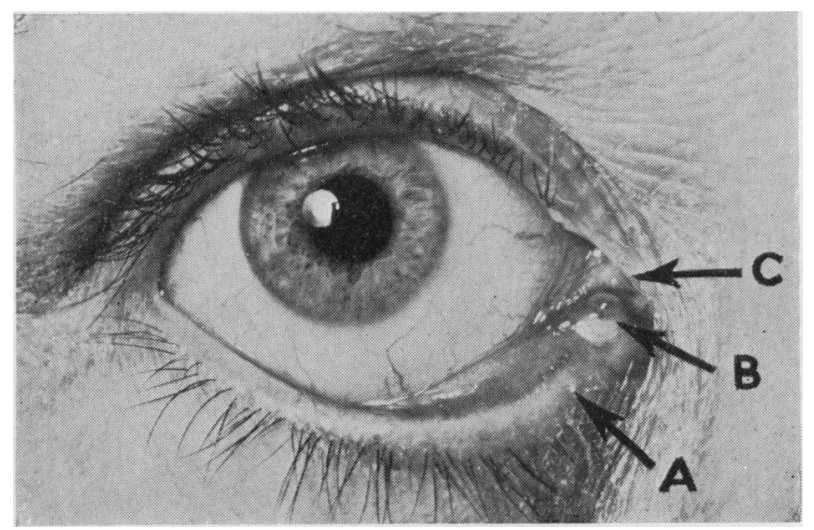

Figure.-Case 6, before treatment. A, position of punctum; B, site of erosion of canaliculus wall; $\mathrm{C}$, position of caruncle.

The punctum was slit for $1 \mathrm{~mm}$. and the concretions curetted out. It was then apparent that the fungus had eroded through the wall of the canaliculus on to the conjunctival surface; a probe could be passed through the slit punctum and out through the wall of the canaliculus, emerging just in front of the caruncle.

No further treatment was given and a month later the patient was free from symptoms, and stated that the discharge had cleared up within a few days of treatment. The canaliculus had healed over with some puckering of the conjunctival surface but the lacrimal passages could be syringed freely and there were no false openings. Probably it would have been better to curette out the contents of the canaliculus in a retrograde manner through the site of erosion without slitting the punctum.

Bacteriological Examination.-Notes on the bacteriological aspects have been made in previous reports (Ruys, 1935; Hagedoorn, 1940; Elliot, 1940; McClanahan, 1930). 
The following report was made by Dr. E. D. Hoare, Pathologist, Edgware General Hospital:

Material removed at operation by curetting the right lower canaliculus was rather dry and whitish-green in colour.

Film. - This showed the presence of pus cells and numerous Gram-positive threads showing true branching. The threads were $0.5 \mu-0.7 \mu$ in thickness, and varied in length from $3 \mu$ to an average of about $8 \mu$ although forms up to $40 \mu$ or $50 \mu$ were not uncommon. The staining of the rods and threads was irregular; they were not acid-fast.

Cultures.-Attempts at primary isolation on the surface of blood agar plates incubated aerobically and anaerobically were unsuccessful after 3 weeks' incubation. The material was incubated in the form of an 0.5 per cent. glucose agar shake culture, and after 6 or 7 days' incubation growth became evident. After 12 to 14 days a turbid band was present about $0.5 \mathrm{~cm}$. in thickness and $1.5 \mathrm{~cm}$. below the surface, consisting of a number of tiny colonies. Deeper in the medium discrete whitish colonies up to $1.5 \mathrm{~mm}$. in diameter were seen, roughly spherical with a coarsely irregular surface.

These discrete colonies in the glucose agar shake culture were successfully grown on the surface of blood agar plates incubated anaerobically but not on those incubated aerobically. After 7 days' incubation the colonies were $0.75-1 \mathrm{~mm}$. in diameter, opaque greyish-white, circular, with a dull and nodular surface. The organisms were of similar morphology to those seen in the films of the material, and were non-motile, non-sporing, Gram-positive, and non-acid fast. This organism had all the characteristics of Actinomyces bovis Harz.

\section{SUMMARY}

Actinomycosis occurs infrequently in ophthalmic practice but perhaps more often than the literature would suggest. Notes have been made in the past 2 years of six cases including one in which there has been invasion of the wall of the canaliculus. Only one such case appears to have been previously recorded.

\section{REFERENCES}

BrinCKerhoff, A. J. (1942). Amer. J. Ophthal., 25, 978.

Chesneau, M. (1908). Ann. Oculist., Paris, 140, 409.

Elliot, A. J. (1941). Amer. J. Ophthal., 24, 682.

Hagedoorn, A. (1940). Arch. Ophthal., Chicago, 23, 689.

KIPP, C. J. (1902). Ibid., 31, 395.

McClanahan, R. (1936). Amer. J. Ophthal., 19, 418.

RUYS, A. C. (1935). British Journal of Ophthalmology, 19, 385.

TheOdore, F. H. (1950). Amer. J. Ophthal., 33, 1225.

Wissmann, R. (1913). Klin. Mbl. Augenheilk., 51 (pt. 1), 287. 